\title{
PKM Pelatihan Penulisan Artikel Ilmiah dan Submission pada Jurnal Ilmiah Nasional bagi Guru SD di Kab. Gowa
}

\author{
Andi Dewi Riang Tati ${ }^{1}$, Widya Karmila Sari Achmad ${ }^{2}$, Erma Suryani Sahabuddin ${ }^{3}$, \\ Sayidiman ${ }^{4}$, Bhakti Prima Findiga Hermuttaqien ${ }^{5}$ \\ 1,2,3,4,5 Pendidikan Guru Sekolah Dasar, Fakultas Ilmu Pendidikan, Universitas Negeri Makassar \\ bhakti@unm.ac.id
}

\begin{abstract}
ABSTRAK
Pengabdian ini dilatarbelakangi oleh rendahnya keterampilan guru sekolah dasar dalam menulis Artikel Ilmiah. Tujuan pengabdian ini adalah untuk melatih guru mengembangkan keterampilan guru dalam menulis artikel ilmiah dan melakukan publikasi pada Jurnal Ilmiah Nasional. Metode pengabdian ini menggunakan metode seminat dan pelatihan. Hasil pengabdian ini adalah guru mampu menulis artikel ilmiah dan submission dengan baik. Implikasi pengabdian ini adalah sebagai acuan oleh praktisi pendidikan untuk meningkatkan keterampilan guru dalam menulis Artikel Ilmiah dan Publikasi Artikelnya.
\end{abstract}

Kata kunci: artikel ilmiah, submission jurnal ilmiah, guru sekolah dasar

\section{ABSTRACT}

This dedication is motivated by the low skills of elementary school teachers in writing scientific articles. The purpose of this study is to train teachers to develop teacher skills in scientific articles and scientific journal submission. This service method uses training methods. The result of this dedication is the teacher is able to scientific articles and scientific journal submission accordingly. The implication of this dedication is as a reference by education practitioners to improve teacher skills in scientific articles and scientific journal submission.

Keywords: scientific articles, scientific journal submission, elementary school teacher.

\section{PENDAHULUAN}

Kegiatan pengembangan profesi guru adalah penerapan keterampilan guru untuk peningkatan mutu pembelajaran dengan menggerakkan seluruh komponen yang menjadi subsistem dalam suatu sistem mutu pendidikan (Ginting \& Haryati, 2012). Subsistem utama dalam peningkatan mutu pendidikan adalah faktor tersedianya guru yang profesional dengan kualifikasi dan kompetensi yang mampu memenuhi tuntutan tugasnya selama proses belajar mengajar berlangsung (Irwandi, 2016).

Guru yang profesional adalah guru yang selalu meningkatkan kompetensinya secara berkesinambungan, selalu kreatif, inovatif, serta menganalisis kelebihan dan kekurangan terhadap apa yang telah dilakukan dalam proses belajar mengajar yaitu melalui kegiatan Penelitian Tindakan Kelas (Siregar, 2014).

Dengan melakukan PTK para guru memperoleh banyak keuntungan. PTK dapat menumbuh kembangkan budaya meneliti bagi tenaga kependidikan agar lebih proaktif serta meningkatkan kolaborasi antar tenaga pendidik dan tenaga kependidikan dalam memecahkan masalah pembelajaran (Mawardi, 2014). PTK dapat meningkatkan mutu proses pembelajaran, dapat meningkatkan kompetensi guru, dan dapat digunakan untuk memenuhi tuntutan tugas sebagai seorang pendidik yang professional (Sukanti, 2014). Dengan memahami dan mencoba melaksanakan PTK, diharapkan kemampuan pendidik dalam proses pembelajaran makin meningkat kualitasnya dan sekaligus meningkatkan kualitas pendidikan serta profesi pendidik/tenaga kependidikan yang sekarang dirasakan menjadi hambatan. Selain memperbaiki kualitas pendidikan, PTK juga dapat dijadikan sebagai inovasi pembelajaran, pengembangan kurikulum, pengembangan profesi guru dan peningkatan mutu pembelajaran (Siregar, 2014). Oleh sebab itu guru harus melaksanakan PTK untuk mencapai tujuan yang baik dalam proses pembelajaran termasuk pada guru SD

Permasalahan yang cukup dilematik dialami guru adalah hasil karya tulis ilmiah 
yang dibuat belum sesuai harapan tim penilai, sehingga banyak para guru yang tertahan kenaikan pangkatnya di golongan IVA, karena untuk naik ke IVB para guru harus memenuhi unsur pengembangan profesi menyusun karya tulis ilmiah salah satunya dalam bentuk jurnal Ilmiah yang terpublikasi (Pramswari, 2016).

Publikasi jurnal ilmiah oleh guru yang minim memaksa para guru untuk menunda kenaikan pangkatnya. Menurut Zamroni Direktur Profesi Pendidik pada Ditjen Mutu Pendidik dan Tenaga Kependidikan, pada saat ini terdapat sekitar 390.000 guru yang berpangkat IV/a masih mengalami kesulitan untuk kenaikan pangkat berikutnya karena adanya persyaratan menulis karya ilmiah (Kompas, 2010). Pernyataan Zamroni tersebut sejalan dengan FX Djoko Soekastomo yang menyebutkan bahwa guru yang telah mencoba melengkapi persyaratan guna mencapai IV/b belum tentu bisa lolos terbentur pada Karya Tulis Ilmiah, masih banyak revisi, perbaikan, dan penyempurnaan, bahkan ada yang ditolak tim penilai karena belum sesuai standar yang diharapkan. (Widagdo, 2018). Dengan demikian, menulis karya ilmiah merupakan syarat mutlak bagi guru yang akan naik pangkat. Selain itu, kemampuan menulis karya ilmiah akan membuat guru menjadi seorang pendidik yang profesional (Sumartini et al., 2019).

Berdasarkan hasil wawancara pengabdi dengan kepala KKG Gugus 1 Kabupaten Gowa dan pengawas serta kepala sekolah. Ditemukan banyak permasalahan-permasalahan guru salah satunya yaitu untuk kenaikan pengkat. Banyak guru, pengawas dan kepala sekolah yang pangkatnya berhenti di golongan IV a. Permasalahan yang mereka hadapi adalah kurangnya pemahaman mereka tentang bagai mana menulis artikel ilmiah dalam hal ini jurnal ilmiah, ditambah mereka semakin bingung dengan keharusan publikasi artikel tersebut di jurnal ilmiah nasional bereputasi.

Melihat esensi pentingnya menulis karya ilmiah sebagai syarat mutlak bagi guru yang akan naik pangkat. Selain itu, kemampuan menulis karya ilmiah akan membuat guru menjadi seorang pendidik yang professional. Maka Tujuan pengabdian ini adalah untuk melatih guru mengembangkan keterampilan guru dalam menulis artikel ilmiah dan melakukan publikasi pada Jurnal Ilmiah Nasional.

\section{METODE KEGIATAN}

Peserta pengabdian ini adalah guru SDN KKG Gugus 1 Kabupaten Gowa. Pelatihan ini dipusatkan di SDN Centre Manggalli Kec. Pallangga. Peserta dalam kegiatan ini berjumlah 60 orang guru. Metode pelaksanaanya yaitu dengan menggunakan metode seminar secara luring dan pelatihan secara blended. Adapun penjelasanya sebagai berikut:

\section{Seminar mengenai Penulisan Artikel Ilmiah dan publikasi Ilmiah.}

Pada PKM ini diberikan seminar kepada guru SD. Seminar ini bertujuan untuk memberikan informasi kepada guru SD mengenai konsep artikel ilmiah, dan cara penulisan artikel ilmiah. Pada kegiatan ini guru dibekali informasi mengenai pentingnya artikel ilmiah, ciri-ciri artikel ilmiah, syarat artikel ilmiah, jenis-jenis artikel ilmiah, dan cara penulisan artikel ilmiah serta langkah-langkah menulis artikel ilmiah dalam bentuk jurnal.

Luaran kegiatan ini adalah meningkatnya pengetahuan guru dalam konsep artikel ilmiah dan pengetahuan menulis artikel ilmiah dalam bentuk jurnal.

2. Pelatihan Pengembangan dan Pelaksanaan Penulisan artike ilmiah dan submission di jurnal nasional.

Pada tahap ini guru dilatih untuk mengembangkan Artikel Ilmiah dalam bentuk Jurnal lalu mensubmitnya ke jurnal Ilmiah nasional terakreditasi.

Luaran kegiatan ini adalah meningkatnya keterampilan guru dalam menulis jurnal ilmiah nasional dan submit artikelnya di jurnal nasional terakreditasi.

Pengukuran ketercapaian kegiatan ini dilakukan dengan evaluasi penguasaan konsep dan ketrampilan dalam menulis dan mensubmit artikel ilmiah di jurnal Nasional. Peserta dikatakan berhasil ketika mencapai nilai skor rata diatas 75 dan mendapatkan skor diatas 75 untuk setiap rata-rata indikator penulisan jurnal ilmiah serta mampu menulis artikel dan submit di jurnal nasional terakreditasi.

\section{HASIL \& PEMBAHASAN}

Pembahasan akan dibagi menjadi dua bagian utama yaitu pembahasan secara luring dan pelatihan secara blended. Adapun penjelasanya sebagai berikut:

1. Seminar mengenai Penulisan Artikel Ilmiah dan publikasi Ilmiah

Proses seminar secara luring mengenai Penulisan Artikel Ilmiah dan publikasi Ilmiah 
dilaksanakan pada hari Sabtu tanggal 04 Juli 2020 kepada 60 orang guru di Sekolah Dasar dan KKG Gugus I Kecamatan Pallangga, Kabupaten Gowa. Penyampaian materi mengenai konsep dasar penulisan artikel ilmiah dan langkah-langkah menulis artikel ilmiah disampaikan pada pertemuan awal dengan tujuan untuk meningkatkan pengetahuan guru mengenai artikel ilmiah dan bagaimana menuliskannya dalam jurnal ilmiah.

Pemateri pada seminar ini adalah Dr. Erma Suryani Sahabuddin, M. Si. dan Andi Dewi Riang Tati, S.Pd., M.Pd. Beliau menyampaikan konsep dasar menulis artikel ilmiah dan langkah-langkah dasar dalam menulis arikel ilmiah dalam bentuk jurnal. Beliau juga berbagi tips dan trik serta pengalamannya selama ini dalam menulis karya tulis ilmiah dalam bentuk jurnal ilmiah nasional. Proses interaksi dengan peserta berlangsung secara interaktif, karena peserta juga melakukan sharing pengalamannya selama ini dalam menuliskan artikel ilmiah serta kendala-kendala yang dihadapi selama ini dalam melakukan penulisan artikel ilmiah. Secara keseluruhan materi yang disampaikan kepada peserta diantaranya :

1) Pentingnya artikel ilmiah untuk menunjang kenaikan pangkat guru dan peningkatan kapasitas pendidik dalam meningkatkan kualitas pembelajaran.

2) Ciri-ciri artikel ilmiah

3) Syarat-syarat artikel ilmiah

4) Bahasa Artikel Ilmiah

5) Jenis-jenis artikel ilmiah

6) Kerangka dan sistematika penulisan artikel ilmiah

7) Teknik Penulisan Artikel Ilmiah

8) Konsep Penulisan jurnal ilmiah nasional

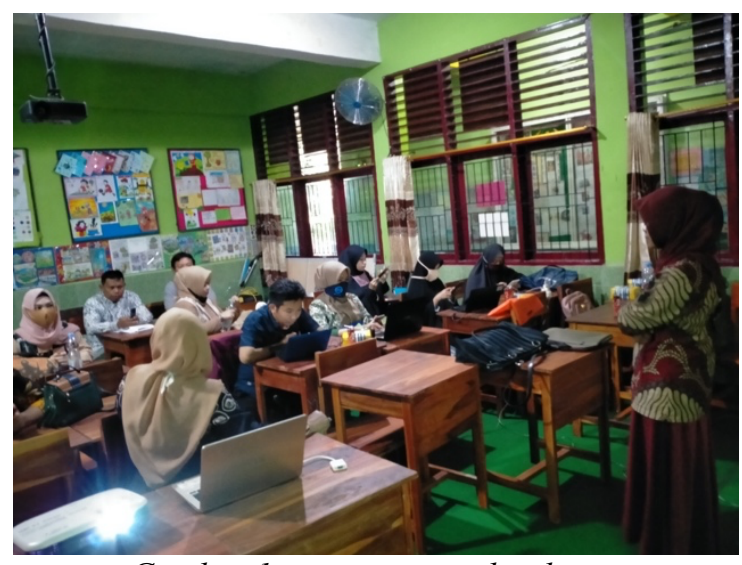

Gambar 1. pemateri memberikan materi

Pemateri juga memberikan kesempatan kepada para peserta pelatihan untuk diskusi dan sharing pendapat terkait pengalaman dalam menulis artikel ilmiah. Pada saat diskusi kendala-kendala yang dihadapi guru dalam menulis artikel ilmiah diantaranya :

1) Kurangnya pengetahuan para guru terhadap artikel ilmian

2) Kurangnya waktu untuk menulis artikel ilmiah, karena selama ini mereka terlalu sibuk dengan urusan administratif sekolah.

3) Tidak ada bimbingan yang simultan dalam menulis artikel ilmiah

Melalui PKM ini para guru sangat terbantu dalam mengatasi permasalahan-permasalahan yang selama ini dihadapi. Karena secara keseluruhan keinginan mereka untuk berkembang cukup tinggi, hal ini dibuktikan dengan tingginya minat mereka dalam mengikuti kegiatan.

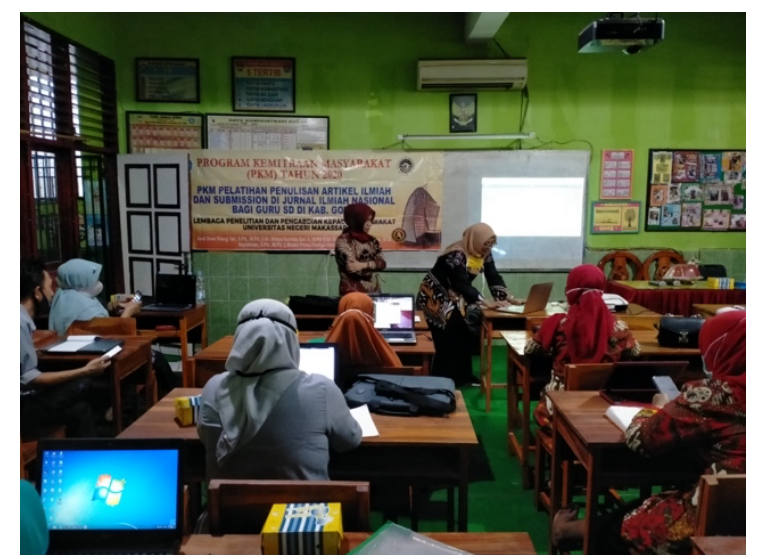

Gambar 2. pemateri memberikan Materi

Pada akhir seminar tersebut pemateri menyampaikan bahwa sejatinya artikel ilmiah merupakan sarana peningkatan kompetensi literasi. Karena dengan guru memahami literasi maka akan memudahkan guru dalam mengajarkan literasi pada peserta didik. Hal yang disampaikan tersebut juga sejalan dengan pendapat Sumartini, Mulyani, \& Nugroho (2019) yang menyatakan bahwa artikel ilmiah merupakan sarana membuat guru menjadi seorang pendidik yang profesional.

\section{Pelatihan Pengembangan dan}

Pelaksanaan Penulisan artikel ilmiah dan submission di jurnal nasional.

Pada pelatihan secara blended yang dilaksanakan pada tanggal 04 sampai 06 Juli 2020. Guru dibekali ketrampilan untuk menulis jurnal ilmiah dari hasil PTK yang telah dibuat dan submit di jurnal nasional terakreditasi. Kegiatan-kegiatan yang dilaksanakan terdiridari : Pengantar jurnal ilmiah nasional, Mencari jurnal yang cocok sesuai dengan kajian 
penlitian, menyusun artikel sesuai dengan template jurnal, Submission di jurnal ilmiah nasional terakreditasi.

Pemateri pada pelatihan ini adalah Bapak Bhakti Prima Findiga Hermuttaqien, S.Pd., M.Pd. dan Sayidiman, S.Pd.,M.Pd.. Pemateri menyampaikan materi tentang :

1) Definisi Jurnal Ilmiah

2) Struktur Jurnal Ilmiah

3) Penjelasan bagian-bagian jurnal

4) Tips mencari jurnal nasional terakreditasi

Untuk kegiatan praktek pendampingan penulisan jurnal ilmiah nasional dan submission dilakukan secara blended, dengan berbantu google classroom.

Awal penyampaian pemateri menyatakan bahwa format setiap jurnal ilmiah berbeda-beda tergantung dengan gaya selingkungan yang telah disepakati oleh pengelola jurnal. Adapun komponen utama yang selalu ada adalah (1) judul, (2) Abstrak, (3)Pendahuluan, (4) Metode, (5) Hasil\&Pembahasan (6) Kesimpulan\&saran (7) Daftar Pustaka.

Pemateri menyampaikan bahwa judul harus jelas, karena judul sebagai kunci untuk mengetahui isi jurnal tanpa harus membaca keseluruhan dari jurnal tersebut. Sehingga judul harus mampu merepresentasikan isi dari pembahasan kita. Usahakan judu tidak melebihi 14 kata. Sehingga judul harus singkat, padat dan jelas. Berikutnya penulisan nama tanpa gelar dan disertai nama lebaga serta email dari penulis.

Setelah judul dan nama, pemateri membahas mengenai Abstrak. Beliau menyampaikan bahwa dalam penulisan abstrak tidak lebih dari 250 kata dan didalamnya mencakup tujuan penelitian, metode penelitian, hasil dan kesimpulan penelitian. Cara mudah untuk menulis abstrak adalah dengan mengutip poin-poin penting pada bagian isi jurnal yang disesuikan dengan format abstrak. Diakhir abstrak ada kata kunci yang harus disertakan, kata kunci terdiri dari 3-5 kata yang diambil dari inti pembahasan penelitian.

Pendahuluan harus berisi berisi latar belakang mengatasi suatu permasalahan, urgensi dan rasionalisasi penelitian, tinjauan pustaka, rencana pemecahan masalah, tujuan penelitian, dan pengembangan hipotesis. Didalam pendahuluan harus mencantumkan kebaharuan dari penelitian yang kita kaji.

Metode penelitian menjelaskan tentang: pendekatan, ruang lingkup atau objek, definisi operasional variable/ deskripsi fokus penelitian, tempat, populasi dan sampel/informan, bahan dan alat.
Hasil penelitian disajikan dengan lengkap dan sesuai ruang lingkup penelitian. Hasil penelitian dapat dilengkapi dengan tabel, grafik (gambar), dan/atau bagan. Tabel dan gambar diberi nomor dan judul. Hasil analisis data dimaknai dengan benar. Bagian pembahasan memaparkan hasil penemuan secara logis, mengaitkan dengan sumber rujukan yang relevan. Hasil menguraikan tentang pelaksanaan seluruh tahapan kegiatan pengabdian. Dapat dilengkapi dengan foto proses dan hasil kegiatan pengabdian. Pembahasan berisi tentang dampak kegiatan pengabdian bagi mitra pengabdian dan analisisnya diperkuat dengan teori dan data yang mendukung dan memperkuat hasil pengabdian.

Kesimpulan berisi rangkuman singkat atas hasil kegiatan penelitian. Hasil penelitian hendaknya juga memberikan saran/kontribusi/implikasi terhadap aplikasi dan/atau pengembangan ilmu pengetahuan. Daftar Pustaka memuat sumber-sumber yang dirujuk danminimal $80 \%$ berupa pustaka terbitan 10 tahun terakhir. Daftar rujukan ditulis sesuai yang disusunsesuai dengan American Psychological Association (APA) Fifth edition.

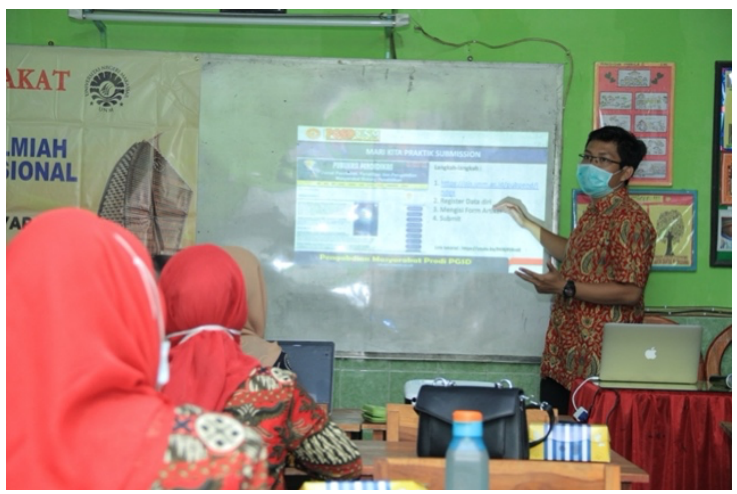

Gambar 3. Pemateri memberikan pelatihan

Selanjutnya pemateri melakukan pendampingan mengenai bagaimana penulisan artikel ilmiah dan bagaimana submission di jurnal Ilmiah nasional. Pelaksanaan pendampingan berlangsung 3 hari melalui google classroom dan google meet. Pelaksanaan berlangsung lancar dimana keseluruhan peserta sudah mampu melakukan submission artikel ilmiah di jurnal Publikasi Pendidikan. Keseluruhan artikel ilmiah yang disubmit di junal Publikasi Pendidikan sudah sesuai dengan template yang telah ditentukan. 


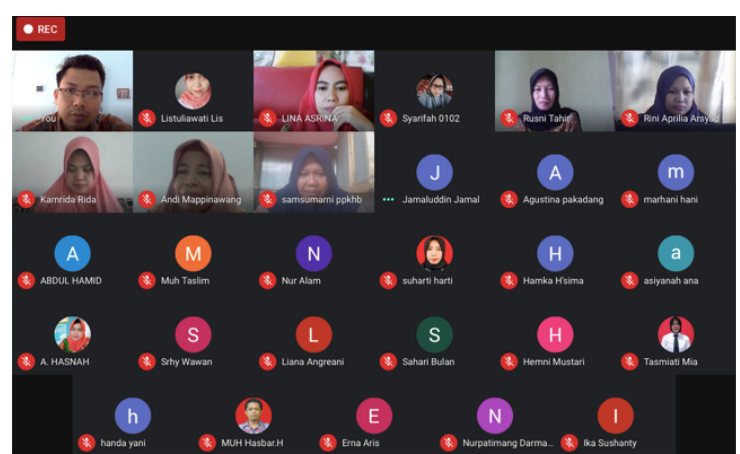

Gambar 5. Pendampingan secara daring melalui google meet

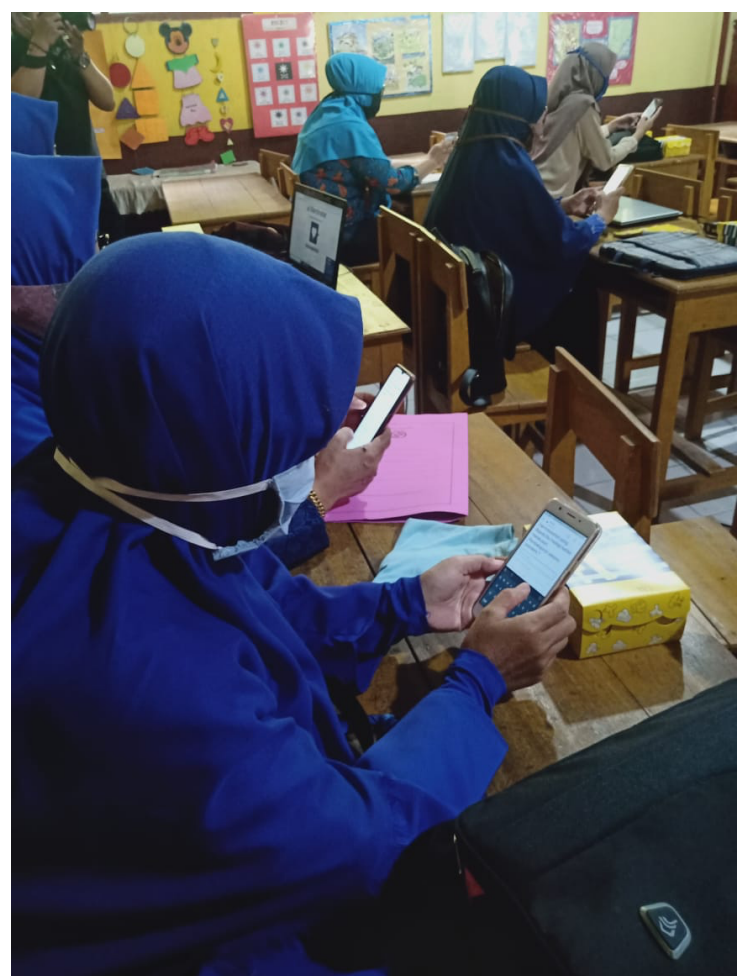

Gambar 6. Peserta mengisi survei

Setelah pengabdian berakhir maka pengabdi melakukan analisis keberhasilan kegiatan. Untuk melakukan analisis maka perlu penyajian data hasil penilaian pemahaman konsep dan penilaian keterampilan. Hasil penilaian rata-rata pemahaman konsep guru dapat dilihat pada grafik dibawah ini:

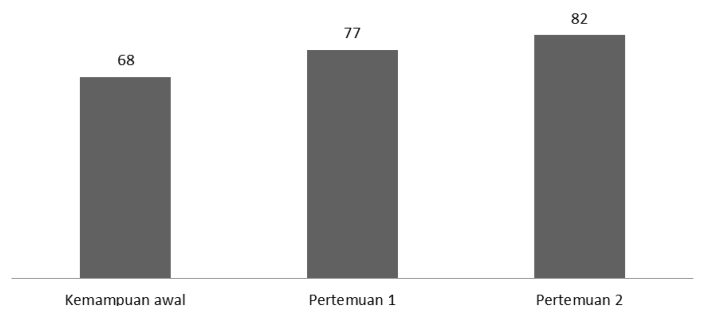

Garfik 1 Rata-rata hasil pemahaman konsep guru sekolah dasar
Berdasarkan grafik tersebut terlihat bahwa guru mengalami peningkatakan pengetahuan dan rata-rata kemampuan guru diatas 75 .

Pengabdian ini menunjukkan bahwa guru sekolah dasar telah mampu membuat artikel ilmiah dengan baik. Hal ini disebabkan selama pengabdian berlangsung guru mengikuti kegiatan dengan aktif sehingga tujuan pengabdian tercapai dengan baik. Keaktifan guru selama mengikuti pelatihan akan berpengaruh pada ketercapaian pelatihan (Rahmawati, 2015).

Keaktifan guru membuktikan bahwa guru memiliki motivasi yang tinggi untuk melaksanakan pelatihan Pelatihan Penulisan Artikel Ilmiah Dan Submission pada Jurnal Ilmiah Nasional. Motivasi tersebut berdampak terhadap ketercapaian tujuan pembelajaran (Hasanah, 2010). Hal ini lah yang mempegaruhi keberhasilan dalam pengabdian ini.

\section{KESIMPULAN \& SARAN}

Kesimpulan dari kegiatan pengabdian kepada masyarakat Pelatihan Penulisan Artikel Ilmiah Dan Submission pada Jurnal Ilmiah Nasional Bagi Guru SD di Kab. Gowa yaitu :

1. Guru-guru SD di Gugus 1 Kabupaten Gowa telah memiliki pengetahuan terkait artikel ilmiah dan jurnal ilmiah nasional terakreditasi.

2. Guru-guru telah memiliki ketrampilan dalam menulis artikel ilmiah dan submit di jurnal ilmiah Nasional terakredtasi.

3. Kegiatan pengabdian kepada masyarakat ini berlangsung lancar

Berdasarkan kesimpulan dari kegiatan diatas maka saran-saran yang dapat penulis berikan untuk para guru SD di Gugus 1 Kabupaten Gowa :

1. Supaya selalu melatih kemapuan dalam menulis karya tulis ilmiah dalam bentuk jurnal ilmiah nasional terakreditasi, karena melalui pembiasaan dalam menulis akan meningkatkan keterampilan dalam menulis.

2. Supaya selalu belajar secara mandiri terkait bagaimana proses sirkulasi artikel sampai terbit

\section{DAFTAR PUSTAKA}

Ginting, R., \& Haryati, T. (2012). Kepemimpinan dan Konteks Peningkatan Mutu Pendidikan. Jurnal Ilmiah CIVIS, II (2), 
http://journal.upgris.ac.id/index.php/civis /article/view/455

Hasanah, D. S. (2010). Pengaruh Pendidikan Latihan (diklat) Kepemimpinan Guru dan Iklim Kerja Terhadap Kinerja Guru Sekolah Dasar se Kecamatan Babakancikao Kabupaten Purwakarta. Jurnal Pendidikan Pelatihan, 11(2), 90105.

http://jurnal.upi.edu/3451/view/1347/pen garuh-pendidikan--latihan-(diklat)kepemimpinan-guru--dan-iklim-kerjaterhadap-kinerja-guru-sekolah-dasar-sekecamatan-babakancikao-kabupatenpurwakarta.html

Irwandi. (2016). Profesionalisme dan Sertifikasi Guru Di Era Reformasi Pendidikan. PIONIR: Jurnal Pendidikan, 5(2), 1-10. https://jurnal.arraniry.ac.id/index.php/Pionir/article/view /3363

Kompas. (2010, March). Lemah, Kemampuan Guru Menulis Karya Ilmiah. Kompas. Com.

Mawardi. (2014). Pemberlakuan Kurikulum SD/MI Tahun 2013 dan Implikasinya Terhadap Upaya Memperbaiki Proses Pembelajaran Melalui PTK. Scholaria: Jurnal Pendidikan Dan Kebudayaan, 4(3), 107-121. https:/ejournal.uksw.edu/scholaria/article /view/96

Pramswari, L. P. (2016). Persepsi Guru SD terhadap Penelitian Tindakan Kelas. Mimbar Sekolah Dasar, 3(1), 53-68. https://doi.org/10.17509/mimbarsd.v3i1.2355

Rahmawati, S. (2015). Pengaruh Pelatihan, Pengalaman Mengajar Dan Kompensasi Terhadap Profesionalisme Guru Di Smk Negeri 3 Palu. Katalogis, 3(12), 67-75. http://jurnal.untad.ac.id/jurnal/index.php/ Katalogis/article/view/6482

Siregar, E. (2014). Pengembangan profesionalisme guru melalui penelitian tindakan kelas. Jurnal Pengabdian Kepada Masyarakat, 20(77), 173-186. https://jurnal.unimed.ac.id/2012/index.ph p/jpkm/article/view/3398/3055

Sukanti, S. (2014). Meningkatkan Kompetensi Guru Melalui Pelaksanaan Penelitian Tindakan Kelas. Jurnal Pendidikan Akuntansi Indonesia, 6(1), 1-11. https://doi.org/10.21831/jpai.v6i1.1786

Sumartini, Mulyani, M., \& Nugroho, B. A. (2019). Workshop Penulisan Karya Ilmiah Bagi Guru. Jurnal Puruhita, 1(1), 54-59.
Widagdo, A. S. (2018). Pelatihan Penulisan Artikel Ilmiah Bagi Guru-guru SD Di Kecamatan Kendal. Abdimas Unwahas, 3(3), 25-29. 